ks. Krzysztof Warchałowski

\title{
Władza rodzicielska a wolność religijna dziecka w prawie polskim
}

Omówienie powyższego zagadnienia ujętego w tak sformułowanym temacie sprowadza się do przeanalizowania istoty władzy rodzicielskiej, zasad jej sprawowania przez rodziców oraz praw przynależnych dziecku ze szczególnym uwzględnieniem prawa do wolności sumienia i wyznania w kontekście rozwiązań prawnych przyjętych przez polskiego ustawodawcę.

\section{Pojęcie władzy rodzicielskiej}

W polskim prawie nie ma ustawowej definicji pojęcia „władza rodzicielska”. Nie formułuje jej zatem ani Kodeks Rodzinny i Opiekuńczy, ani żaden inny akt prawny. W tym względzie możemy zatem odwołać się do ustaleń doktryny, która bazuje na wykładni przepisów kodeksowych normujących tę problematykę, a zwłaszcza art. 95, 96 i $98 \mathrm{KRO}$. Analiza powyższych unormowań daje podstawę do przyjęcia, że władza rodzicielska jest to ogół obowiązków spoczywających na rodzicach i praw im przysługujących względem dziecka, mających na celu należyte wykonywanie pieczy nad jego osobą i majątkiem¹. Bardziej szczegółowo precyzuje tę definicję Seweryn

1 H. Ciepła i in., Kodeks rodzinny i opiekuńczy. Komentarz, Warszawa 2011, art. $92 / 1$. 
Szer, według którego władza rodzicielska stanowi zespół przysługujących rodzicom z mocy kodeksu rodzinnego i opiekuńczego praw i obowiązków obciążających ich z mocy tego kodeksu, a dotyczących w szczególności pieczy nad dzieckiem w zakresie jego osoby i majątku, a także wychowania ${ }^{2}$. W tym przypadku autor podkreślił zgodnie z art. 95 k.r.o., że wychowanie dziecka należy do fundamentalnych praw i obowiązków rodziców i tym samym stanowi integralny element władzy rodzicielskiej. Inny przedstawiciel doktryny, definiując omawiane pojęcie władzy rodzicielskiej, dodatkowo eksponuje obowiązek przygotowania dziecka do pracy odpowiednio do jego uzdolnień, co pozostaje w zgodzie z art. 96 k.r.o.3. Ponadto doktryna, precyzując analizowany termin, podkreśla także zasady stanowiące kryterium sprawowania władzy rodzicielskiej, którymi są dobro dziecka i interes społeczny ${ }^{4}$. W konsekwencji należy jednak stwierdzić, że istota władzy rodzicielskiej sprowadza się do określenia jej jako zespołu obowiązków i praw rodziców względem

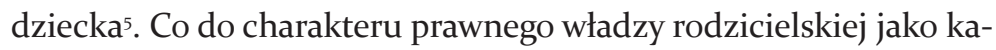
tegorii prawnej należy przyjąć, że jest to stosunek prawnorodzinny, łączący bezpośrednio rodziców z małoletnim dzieckiem. Występują w nim, tak jak w innych stosunkach cywilnoprawnych, dwie strony. Zatem władza rodzicielska ma przymiot prawa podmiotowego, które służy interesom zarówno dziecka, jak i jego rodziców ${ }^{6}$.

\footnotetext{
$2 \quad$ S. Szer, Prawo rodzinne w zarysie, Warszawa 1969, s. 197.

3 B. Dobrzański, Art. 96, [w:] Kodeks rodzinny i opiekuńczy. Komentarz, red. B. Dobrzański, J. Ignatowicz, Warszawa 1975, s. 658.

4 Zob. K. Gromek, Wtadza rodzicielska. Komentarz, Warszawa 2008, s. 103-104.

5 Zob. M. Nasiłowska-Osik, Władza rodzicielska a prawa dziecka, „Przegląd Prawno-Ekonomiczny" (2011) nr 3, s. 64.
}

6 H. Ciepła i in., Kodeks..., dz. cyt., s. art. 92/5. W doktrynie istnieje także pogląd traktujący władzę rodzicielską jako funkcje społeczną. Wydaje się, że jest 


\section{Podmioty władzy rodzicielskiej}

Zgodnie z tymi podmiotami władzy rodzicielskiej z jednej strony są obydwoje rodzice, którym Kodeks rodzinny i opiekuńczy, urzeczywistniając zasadę równouprawnienia kobiety i mężczyzny, przyznaje jednakowe prawa w zakresie sprawowania tej władzy bez względu na to, czy rodzice są małżeństwem, czy nie. Nie oznacza to, że uprawnienia każdego z rodziców składają się na całość władzy rodzicielskiej. Każdego z rodziców, któremu przysługuje władza rodzicielska, łączy z dzieckiem odrębny stosunek prawnorodzinny, którego treść stanowi wspomniana władza. Co do zasady każdy z tych stosunków prawnych jest samodzielny, a każdemu z rodziców przysługuje pełnia władzy z wyjątkiem istotnych praw dziecka, o których rozstrzygają rodzice wspólnie, a w przypadku braku porozumienia między nimi rozstrzyga sąd opiekuńczy (art. 97 k.r.o.). Należy oczywiście dodać, że oprócz naturalnych rodziców podmiotami uprawnionymi są także inne osoby sprawujące pieczę nad dzieckiem, do których zalicza się rodziców adopcyjnych oraz prawnych opiekunów.

Drugą stronę stosunku prawnego, jaki kreuje władza rodzicielska, a zarazem jej podmiot, stanowi dziecko. Władza rodzicielska trwa aż do jego pełnoletności i po jej uzyskaniu wygasa ex lege $e^{8}$.

to pogląd mniej trafny, mający znacznie mniejsze grono zwolenników, zob. A. Łapiński, Ograniczenie władzy rodzicielskiej w polskim prawie rodzinnym, Warszawa 1975, s. 22.

$7 \quad$ Nie omawiam kwestii szczegółowych związanych z powstaniem władzy rodzicielskiej ani możliwościami jej ograniczenia, ponieważ zagadnienia te nie wpisują się w główny nurt podjętych rozważań.

8 T. Smyczyński, Prawo rodzinne i opiekuńcze, Warszawa 2005, s. 202-203. Inne przyczyny ustania władzy rodzicielskiej: zob. J. Gajda, Kodeks rodzinny i opiekuńczy. Komentarz, Warszawa 2000, s. 370. 


\section{Zasady wykonywania władzy rodzicielskiej}

Generalną dyrektywę wykonywania władzy rodzicielskiej zawiera art. $95 \S 3$ k.r.o., który nakazuje rodzicom wykonywanie tej władzy dla dobra dziecka i zgodnie z interesem społecznym. Według zgodnego poglądu przedstawicieli doktryny prawa rodzinnego dobro dziecka stanowi zatem główne kryterium należytego sprawowania władzy rodzicielskiej. Odwołanie się ustawodawcy do zgodności sprawowania tej władzy z interesem społecznym wskazuje, że rodzice mają obowiązek przygotować dziecko do pracy dla społeczeństwa odpowiednio do jego uzdolnień, a wykonywanie władzy rodzicielskiej ma nie tylko wymiar wewnątrzrodzinny. Oznacza to, że społeczeństwu nie jest obojętne, jak przez rodziców będzie wykonywana władza rodzicielska i jaki będzie końcowy efekt pro-

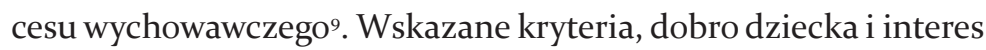
społeczny są ze sobą zbieżne, gdyż działanie zgodne z interesem dziecka nie może być sprzeczne z interesem ogólnospołecznym ${ }^{10}$. Zgodnie z tym przyjmuje się, że „dobro dziecka” to zespół wartości o charakterze zarówno materialnym, jak i niematerialnym, niezbędny do zapewnienia prawidłowego rozwoju fizycznego i duchowego dziecka oraz do należytego przygotowania go do pracy odpowiednio do jego uzdolnień, przy czym wartości te są zdeterminowane przez wiele różnorodnych czynników, których struktura zależy od treści stosowanej normy prawnej i konkretnej, aktualnie istniejącej sytuacji dziecka, zakładając zbieżność tak pojętego dobra dziecka z interesem społecznym" ${ }^{11}$.

9 A. Gałakan-Halicka, Zasady wykonywania władzy rodzicielskiej, „Rzeszowskie Studia Prawnicze” 1 (2011), s. 218, J. Strzebińczyk, Prawo rodzinne, Kraków 2003 , s. 308.

10 H. Ciepła i in., Kodeks..., dz. cyt., art. 95/4.

11 W. Stojanowska, Rozwód a dobro dziecka, Warszawa 1979, s. 27. 
Wykonywanie władzy rodzicielskiej jest obowiązkiem rodziców i nie mogą się oni jej zrzec ani przenieść tego obowiązku na osoby trzecie. Ustawodawca w kwestii wykonywania władzy rodzicielskiej obdarzył rodziców dużym kredytem zaufania, który w polskim prawie przejawia się zasadą autonomii rodziny i zasadą prymatu rodziców. Zaufanie do rodziców wynika z powszechnego przekonania, że w prawidłowo funkcjonującej rodzinie wyrządzenie dziecku krzywdy należy do rzadkości, a ewentualne uchybienia rodzicielskie rekompensowane są ogromną miłością rodziców do dziecka ${ }^{12}$. Potwierdza to również Sąd Najwyższy, stwierdzając, że więź rodzinna istniejąca między rodzicami a dziećmi i normalne w tych warunkach uczucie miłości z reguły stanowią dostateczną gwarancję prawidłowego wykonywania władzy rodzicielskiej³. Tak rozumiana zasada autonomii rodziców w zakresie wykonywania władzy rodzicielskiej ma podwójny walor samodzielności i wyłączności. Samodzielność rodziców wyraża się w tym, że nie podlegają oni stałemu, bieżącemu nadzorowi sądu opiekuńczego, tak jak ma to miejsce w przypadku ustanowienia opieki nad dzieckiem. Wyłączność zaś sprawowania władzy rodzicielskiej przez rodziców oznacza, że tylko oni są uprawnieni do jej wykonywania i nie mogą spowodować jej ustania ani w drodze jednostronnej rezygnacji, ani na skutek porozumienia zawartego między nimi a dzieckiem ${ }^{14}$.

Jednym z najważniejszych obowiązków rodziców, składającym się na treść władzy rodzicielskiej, jest sprawowanie pieczy nad dzieckiem, jego wychowanie oraz kierowanie nim (art. $95 \S$ 1, art.

12 A. Gałakan-Halicka, Zasady..., dz. cyt., s. 219-220.

13 Uchwała Sądu Najwyższego z dnia 9 czerwca 1976 r., III CZP 46/75, OSNC 1976, nr 9, poz. 184 .

14 A. Gałakan-Halicka, Zasady..., dz. cyt., s. 221-222. 
96 k.r.o.). Przez pojęcie „piecza nad dzieckiem” należy rozumieć stałą troskę o dziecko obejmującą zapewnienie mu odpowiednich warunków życia oraz ochronę przed niekorzystnymi i niebezpiecznymi wpływami innych osób i otoczenia ${ }^{15}$. Jeżeli chodzi o wychowanie, to polski ustawodawca używa tego terminu w sensie szerokim, obejmującym wszelkie oddziaływanie na człowieka tworzące jego osobową indywidualność. Wymienia się w tym kontekście: kształtowanie postaw emocjonalnych, formowanie światopoglądu oraz systemu wartości, rozwijanie predyspozycji intelektualnych oraz umiejętności praktycznych, zaznajamianie dziecka z treścią prawa i zasad współżycia społecznego ${ }^{16}$. Łączące się z wychowaniem kierowanie dzieckiem obejmuje prowadzenie dziecka w rozwoju, odpowiednie ukierunkowanie postępowania, decydowanie o dziecku i za dziecko, dopóki samo nie będzie mogło podejmować określonych decyzji ${ }^{17}$. Pod tym pojęciem doktryna rozumie także decydowanie w sprawach dziecka, które określane są jako istotne. Zalicza się do nich m.in. wybór kierunku nauki, sposób spędzania wolnego czasu, przynależność do organizacji, światopogląd, rozwój zainteresowań i inne ${ }^{18}$. Po stronie dziecka pozostającego pod władzą rodzicielską leży obowiązek posłuszeństwa wobec rodziców (art. 95 § 2 k.r.o.), który stanowi zasadę zachowania dziecka, mającą gwarantować należyte wykonywanie

15 M. Nasiłowska-Osik, Władza..., dz. cyt., s. 66; H. Dolecki, Ingerencja sq̨du opiekuńczego w wykonywanie władzy rodzicielskiej, Warszawa 1983, s. 27.

16 W. Stojanowska, M. Kosek, Prawo i obowiq̨zek rodziców do wychowania dziecka w świetle kodeksu rodzinnego i opiekuńczego, „Studia Płockie” 41 (2013), S. 224 .

17 J. Winiarz, J. Gajda, Prawo rodzinne, Warszawa 2001, s. 209.

18 Zob. M. Andrzejewski, Prawo rodzinne i opiekuńcze, Warszawa 2006, S. $138-139$. 
władzy rodzicielskiej jego rodzicom, co oznacza podporządkowanie się przez dziecko ich woli. Obowiązek ten jest niezbędnym czynnikiem każdego wykonywania władzy rodzicielskiej. Rodzice swoim przykładem, perswazją i pozytywnym wpływem na psychikę, osobowość i emocje dziecka dążą do podporządkowania się ich życzeniom i poleceniom ${ }^{19}$. Zdaniem niektórych przedstawicieli doktryny nałożenie na dziecko obowiązku posłuszeństwa swym rodzicom jest przykładem normy bez sankcji, której celem jest wyrażenie przez ustawodawcę modelowego ujęcia relacji rodzice-dzieci ${ }^{20}$.

\section{Prawo rodziców do wychowania dziecka zgodnie z własnymi przekonaniami a podmiotowość dziecka w zakresie prawa do wolności religijnej}

W zakres uprawnień wychowawczych rodziców wchodzi prawo do wychowania dziecka zgodnie z własnymi przekonaniami. Potwierdza to przepis art. 53 § 3 wraz z art. 48 Konstytucji RP z 2 kwietnia 1997 roku, w myśl których rodzice mają prawo do zapewnienia dzieciom wychowania i nauczania moralnego i religijnego zgodnie ze swoimi przekonaniami (art. 53 §), przy czym art. 48 § 1 zawiera klauzulę nakazującą rodzicom uwzględnienie przy tym stopnia dojrzałości dziecka, a także wolność jego sumienia i wyznania oraz jego przekonania ${ }^{21}$. Tym samym ustawodawca konstytucyjny uznał wyraźnie podmiotowość dziecka w zakresie praw człowieka, w szczególności w kwestiach związanych z prawem do wolności sumienia i religii, z czego wynika skierowany do rodziców nakaz

\footnotetext{
19 H. Ciepła i in., Kodeks..., dz. cyt., art. 95/10.

2 K. Gromek, Władza..., dz. cyt., s. 114.

21 Dz.U. z 1997 r. Nr 78, poz. 483 z późn. zm.
} 
odpowiedniego jej uszanowania w procesie wychowawczym ${ }^{22}$. Z przepisu konstytucyjnego wynika jasno, że konstytucja RP podkreśla ochronę praw rodziców w zakresie wychowania dzieci zgodnie z ich przekonaniami religijnymi i moralnymi, chroniąc pozostającą z nią w korelatywnym związku ochronę prawa do wolności religijnej należnej dziecku. Z faktu, że dziecko jest osobą, wynika, że nie jest ono i nie może być tylko przedmiotem opiekuńczej troski rodziców i innych osób uprawnionych, ale jest podmiotem określonych praw i wolności, w tym przypadku wolności religijnej ${ }^{23}$. Nie ulega wątpliwości, że podmiotem prawa do wolności religijnej jest każdy człowiek, a więc i osoba małoletnia. Potwierdza to ratyfikowana przez Polskę Konwencja o prawach dziecka, przyjęta przez Zgromadzenie Ogólne Narodów Zjednoczonych 20 listopada 1989 roku $^{24}$, która w art. 14 § 1 gwarantuje, że państwa - strony będą respektowały prawo dziecka do swobody myśli, sumienia i religii, korelując jednak wymienione prawo dziecka z prawami i obowiązkami rodziców i odpowiednio opiekunów prawnych odnośnie do ukierunkowania dziecka w korzystaniu z jego prawa do wolności religijnej w sposób zgodny z rozwijającymi się zdolnościami. W konsekwencji problem dotyczy ustalenia relacji zachodzących między konkretnymi uprawnieniami rodziców a wolnością religijną dzieci z uwzględnieniem wskazania, że zakres praw dziecka powinien być stale rozszerzany wraz z postępującym jego rozwojem oraz wzrostem zdolności do korzystania z własnych praw.

22 A. Mezglewski, H. Misztal., P. Stanisz, Prawo wyznaniowe, Warszawa 2011 , s. 69.

23 J. Krukowski, Ochrona wolności myśli, sumienia i religii dziecka, „Roczniki Nauk Prawnych" 13 (2003) z. 2, s. 5-6.

24 Dz.U. z 1991 r. Nr 120, poz. 526 z późn. zm. 
Problematyka określenia korzystania z tego prawa przez dzieci wzbudza wiele kontrowersji, które ujawniają się zarówno w dyskursie naukowym, jak i w opinii społecznejej. Związane jest to z faktem, że jednym z obszarów życia społecznego, wobec którego norma prawna ma jedynie ograniczone możliwości zastosowania, są relacje między rodzicami i dziećmi, a zwłaszcza te, które wiążą się z oddziaływaniem wychowawczym ${ }^{26}$.

W korzystaniu z praw i wolności - w tym prawa do wolności religijnej - dziecko nie jest osobą samodzielną, ponieważ dopóki nie osiągnie ono pełnoletności, jego osobowość nie jest dojrzała. W miarę zbliżania się do pełnoletności zakres jego zdolności prawnej ulega poszerzeniu ${ }^{27}$. Powstaje pytanie, w jaki sposób rodzice winni uwzględnić wzrastającą dojrzałość dziecka i ukierunkować je tak, aby w maksymalnym stopniu zapewnić mu wolność religijną. Wydaje się, że odpowiedzi na to pytanie udziela sam ustawodawca, dając „pewne normatywne wytyczne”. Zawiera je Ustawa zasadnicza oraz Kodeks rodzinny i opiekuńczy, zwłaszcza we wprowadzonej noweli do art. 95 z 6 listopada 2008 roku, będącego podstawowym przepisem w przedmiocie treści władzy rodzicielskiej i obowiązków z niej wynikających. Zmiany wprowadzone przez wymienioną wyżej nowelizację - jak wskazano w jej uzasadnieniu - podyktowane zostały koniecznością dostosowania unormowań kodeksowych dotyczących stosunków między rodzicami i dziećmi do zmienionego społecznego i prawnego

25 A. Jakuszewicz, Prawo rodziców do wychowania dzieci zgodnie z własnymi przekonaniami a wolność sumienia i religii dzieci w Konstytucji RP oraz Konwencji o Prawach Dziecka, Bydgoszcz 2013, s. 116.

26 M. Heine, Prawa dziecka a władza rodzicielska, „Acta Universitatis Wratislaviensis. Prace Pedagogiczne” (1997) nr 117, s. 80-81.

27 J. Krukowski, Ochrona..., dz. cyt., s. 6. 
kontekstu stosowania tych przepisów ${ }^{28}$. Zgodnie z nowelą „władza rodzicielska [...] ma być wykonywana z poszanowaniem praw i godności dziecka" (art. 95 § 1). Sformułowanie to ma postać tzw. „normy programowej” wskazującej na pewien sposób wykonywania władzy rodzicielskiej, podkreśla konieczność uwzględnienia dziecka jako trzeciego obok ojca i matki podmiotu rodzinnej sytuacji prawnej, w tym wypadku także w perspektywie posiadanego prawa do wolności religijnej ${ }^{29}$. Wymóg poszanowania godności dziecka podkreśla jego osobowy i podmiotowy charakter, ponieważ godność człowieka stanowi źródło posiadanych przez niego praw i wolności. Następnie dodany do art. 95 § 4 wymaga, aby rodzice przed powzięciem decyzji w ważniejszych sprawach dotyczących osoby lub majątku dziecka wysłuchali go, jeżeli rozwój umysłowy, stan zdrowia i stopień dojrzałości dziecka na to pozwala, oraz uwzględnić w miarę możliwości jego rozsądne życzenia. Brzmienie tego przepisu nawiązuje do art. 72 ust. 3 Konstytucji, który stanowi, iż organy władzy publicznej oraz osoby odpowiedzialne za dziecko są obowiązane do wysłuchania i w miarę możliwości uwzględnienia zdania dziecka. Obowiązek wynikający z art. 95 § 4 ograniczony został do ważniejszych spraw dotyczących osoby dziecka, do których bezwzględnie należy jego prawo do wolności religijnej. Nie oznacza to jednak, że należy bezkrytycznie przyjmować wszystkie postulaty dziecka w tej sprawie, ale

28 Zob. Uzasadnienie rządowego projektu ustawy o zmianie ustawy Kodeks rodzinny i opiekuńczy oraz niektórych innych ustaw, Druk sejmowy nr 888 (http://www.sejm.gov.pl/).

29 D. Opozda, Rodzicielstwo w pułapce partnerstwa (?): zmiany w rozwoju jako predykator jakości relacji rodzic-dziecko, [w:] Partnerstwo w rodzinie. Istota i uwarunkowania relacji między rodzicami i dziećmi, red. J. Truskolaska, Lublin 2009, s. 153n. 
wskazane jest, aby traktować je z należna uwagą w miarę zbliżania się dziecka do dojrzałości ${ }^{\circ}$. Ciążący na rodzicach obowiązek wysłuchania dziecka podkreśla jego godność i wartość. Bez poszanowania prawa dziecka do wysłuchania w sprawie jego przekonań religijnych dziecko byłoby traktowane przez rodziców jako przedmiot, a nie podmiot ich relacji rodzicielskiej. Chodzi o to, by rodzice nie podejmowali decyzji wychowawczych w zakresie prawa do wolności religijnej dziecka bez wysłuchania jego zdania ${ }^{31}$. Ponadto zgodnie $\mathrm{z}$ art. $95 \S 2$ dziecko jest winne rodzicom posłuszeństwo, a w sprawach, w których może samodzielnie podejmować decyzje i składać oświadczenia woli, powinno wysłuchać opinii i zaleceń rodziców formułowanych dla jego dobra. A więc nawet w sprawach, w których ustawodawca przyznaje dziecku konkretne uprawnienia (np. nawiązanie stosunku pracy - art. $191 \mathrm{kp}$, zawieranie drobnych umów w zakresie życia codziennego - art. 21 kc), wyraża wolę, aby i wówczas dziecko zapoznało się ze stanowiskiem rodziców w tej sprawie.

\subsection{Stanowiska doktryny dotyczące relacji władzy rodzicielskiej i prawa do wolności religijnej dziecka}

Ustalenie zakresu autonomii dziecka w sprawach dotyczących jego prawa do wolności religijnej, wyznaczanego przez kryteria wysłuchania dziecka, osiągnięcia określonego stopnia dojrzałości, rozwoju umysłowego stanowi przedmiot kontrowersji. Wynika to stąd, że pojęcia te mają charakter ocenny, trudny do jednoznacznego sprecyzowania ${ }^{32}$, co - zdaniem niektórych przedstawicieli

\footnotetext{
30 J. Krukowski, Ochrona..., dz. cyt., s. 7 .

31 J. Krukowski, Ochrona..., dz. cyt., s. 14-15; W. Osiatyński, Twoja Konstytucja, Warszawa 1997, s. 137.

32 A. Jakuszewicz, Prawo..., dz. cyt., s. 123.
} 
doktryny - przysparza wielu interpretacyjnych trudności i przyczynia się do osłabienia autorytetu rodziców33.

W związku z tym dają się zauważyć w nauce prawa dwa przeciwstawne stanowiska, które można określić mianem konfrontacyjnego i służebnego.

\subsubsection{Stanowisko konfrontacyjne}

W myśl pierwszego, zakładającego sprzeczność interesów rodziców i dzieci niemożliwą wręcz do pogodzenia, wraz z osiągnięciem pewnego stopnia dojrzałości dzieci powinny korzystać z możliwości wyboru określonych zasad i wartości, nawet jeśliby były one sprzeczne z poglądami i wartościami rodziców. Wśród przedstawicieli tego poglądu można spotkać się z wykładnią, że przepisy nakazujące uwzględnienie stanowiska dziecka mają za zadanie uszczuplenie praw rodziców na rzecz dzieci oraz ochronę dziecka przed presją poglądów wyznawanych przez rodziców, a niepodzielanych czy odrzucanych przez dzieci34. Niektórzy zajmują nawet stanowisko, że w k.r.o. brakuje zapisów obligujących rodziców do szanowania praw i wolności osobistych dziecka, a w tym temacie istnieją pewne „luki”, które są często w sposób świadomy wykorzystywane przez rodziców ${ }^{35}$, lub twierdzą wręcz, że w XXI wieku rodzice i inni dorośli wciąż mają prawo do „molestowania religijnego" dzieci i do gwałtu na ich umysłach. Relacja między rodzicem

P. Sobczyk, Wolność sumienia i religii w art. 53 Konstytucji Rzeczypospolitej Polskiej z dnia 2 kwietnia 1997, „Prawo Kanoniczne” (2001) nr 3-4, s. 213.

34 A. Jakuszewicz, Prawo..., dz. cyt., s. 122n; zob. A. Grzejdziak, Prawo do wychowania w rodzinie, [w:] B. Banaszak, A. Preisner, Prawa i wolności obywatelskie w Konstytucji RP, Warszawa 2002, s. 479; P. Winczorek, Komentarz do Konstytucji Rzeczypospolitej Polskiej z dnia 2 kwietnia 1997 r., Warszawa 2002, s. 40.

M. Nasiłowska-Osik, Władza..., dz. cyt., s. 69. 
a dzieckiem nie jest relacją właściciela i niewolnika. Dzieci mają własne interesy niezależne od interesów rodziców. Wielu prawników, psychologów i pedagogów proponuje wręcz zaniechać stosowania pojęcia władzy rodzicielskiej, a zacząć mówić o rodzicielskim przywileju sprawowania pieczy nad dzieckiem ${ }^{36}$.

\subsubsection{Stanowisko służebne}

Zgodnie z drugim stanowiskiem regulacje wynikające z systemu prawa polskiego dotyczące prawa rodziców do wychowania dzieci zgodnie z własnymi przekonaniami powinny być postrzegane nie jako wyraz antycypacji ewentualnych konfliktów miedzy rodzicami a dziećmi, lecz jako mechanizm ich rozwiązywania. Ich celem jest uznanie faktu, że dziecko, rozwój jego osobowości oraz realizacja jego praw powierzone została trosce rodziców. We właściwie funkcjonujących rodzinach nie jest bowiem konieczne podkreślanie praw dzieci, o ile nie jest zagrożone ich dobro. Obowiązek uwzględniania stopnia dojrzałości dziecka stanowi nie tyle próbę rozstrzygnięcia konfliktu pomiędzy prawami rodziców oraz kolidującymi z nimi prawami dzieci (uwzględnianie przekonań dzieci nie jest tożsame z obowiązkiem ich akceptacji przez rodziców i zaniechania przez nich stosowania w danej dziedzinie określonych środków wychowawczych), ile raczej wskazówkę o charakterze prakseologicznym, regułę wychowania podyktowaną przez zdrowy rozsądek, której nieprzestrzeganie prowadziłoby do zaprzestania procesu wychowania. Rodzice, nadając kierunek wychowaniu swoich dzieci, powinni dostosować środki i metody wychowawcze do możliwości percepcyjnych dziecka dotyczących przekazywanych mu wartości. Jednakże w sytuacji konfliktu między decyzją rodziców a wolą dzieci w sprawie przekonań religijnych głos rozstrzygający przysługuje

36 H. Postek, Granice władzy rodzicielskiej, „Przegląd” 32 (2007), s. 42. 
rodzicom, przy czym nie powinni oni stosować przymusu, ile raczej „oddziaływać siłą swego autorytetu”. Obowiązek uwzględniania stopnia dojrzałości dzieci oraz ich przekonań sprowadza się więc do wymogu właściwego reagowania w przypadku pojawiania się nowych sytuacji wychowawczych.Omawiany przepis nie tyle więc ustanawia gwarancję praw wychowawczych rodziców wobec ewentualnych roszczeń „emancypacyjnych” ze strony dzieci, ile raczej przewiduje ochronę przed niepożądanymi wpływami z zewnątrz; nikomu bowiem nie wolno narzucać dziecku wychowania moralnego lub religijnego pozostającego w sprzeczności z przekonaniami rodziców. Uwzględnianie stopnia dojrzałości dziecka w procesie wychowawczym nie może prowadzić do uzyskania przez nie „uprzywilejowanej” pozycji kosztem praw rodziców37.

Rozgraniczenie zakresów kolidujących praw ma przebiegać w oparciu o kryterium rozwoju i dojrzałości dzieci, jednakże ani Konstytucja, ani ustawa Kodeks rodzinny i opiekuńczy, ani Konwencja o prawach dziecka nie wskazuje sposobu ustalenia stopnia tegoż rozwoju. Należy więc przyjąć, iż rozstrzygnięcia tego rodzaju muszą być uzależnione od okoliczności danego przypadku, przy czym decydujący głos w tej sprawie przypada rodzicom ${ }^{38}$, ponieważ są oni „naturalnymi dysponentami” ${ }^{39}$ wolności sumienia i wyznania swoich dzieci, co wynika nie tylko z istoty władzy rodzicielskiej, lecz przede wszystkim z naturalnych więzi między rodzicami

37 A. Jakuszewicz, Prawo..., dz. cyt., s. 124n; O. Sitarz, Ochrona wolności sumienia i wyznania dziecka w polskim prawie karnym, „Problemy Prawa Karnego” 25 (2004), s. 14n; P. Sarnecki, Omówienie artykułu 48 Konstytucji, [w:] Konstytucja Rzeczypospolitej Polskiej. Komentarz, red. L. Garlicki, t. III, Warszawa 2003, s. 4.

38 M. Pietrzak, Państwo prawne, państwo świeckie, Warszawa 2012, s. 179.

39 K. Warchałowski, Prawo do wolności myśli, sumienia i religii w Europejskiej Konwencji Praw Człowieka i Podstawowych Wolności, Lublin 2004, s. 195. 
a dziećmi. Trudno więc nie przychylić się do poglądu, zgodnie z którym w procesie ukierunkowania dzieci w korzystaniu z prawa do wolności sumienia i wyznania rodzicom przysługuje znaczny margines swobody, zaś ich stanowisko w sprawie oceny stopnia dojrzałości ich dzieci w zasadzie nie powinno być podważane, o ile nie zachodzi przypadek rażącego nadużycia władzy rodzicielskiej${ }^{40}$.

\section{Konkluzja}

Konkludując, należy powiedzieć, że dziecko jak każdy człowiek jest podmiotem prawa do wolności religijnej, którego naturalnymi dysponentami są rodzice realizujący wobec dziecka obowiązki i prawa wypływające z posiadanej władzy rodzicielskiej. W realizacji władzy rodzicielskiej rodzice powinni mieć świadomość osobowej godności dziecka i ją szanować, uwzględniać jego rozwój umysłowy oraz stopień dojrzałości, wraz z którymi wykształca się u dziecka zdolność samodzielnej oceny i oglądu rzeczywistości oraz zapoznawać się ze zdaniem dziecka, kierując się zawsze przy podejmowanych decyzjach jego dobrem.

SUMMARY

\section{Parental authority and religious freedom of a child in Polish law}

The aim of the paper is to analyze the parental authority in the context of religious freedom. The Author starts with the definition of parental

40 G. Lantier, Freedom of thought, conscience and religion, [w:] J. Todres, M. Wojcik, C. Revaz, The U.N. Convention on the rights of the child. An analysis of treaty provisions and implications of U.S. ratification, New York 2006, s. 160. 
authority in law and the description of the bearers of the power in question. Later on "the welfare of the child" as the ultimate criterion of any legislative action is presented, also the exercising of the parental authority must be exercised according the rule. The parents have the rights to educate their children according to their convictions. Still, they are obliged by law to take under consideration the right of the child for freedom of conscience and belief. The parents must respect the dignity of the child and consider the as long as the mental development, and maturity of the child permit. According to the confrontational stance, the children should have the right to choose their rules and beliefs even when they are contrary to their parents. According to the ancillary stance, the parents have the final word in this matter.

Keywords: parental authority, parents, child, religion, the welfare of the child

ks. Krzysztof Warchałowski, Władza rodzicielska a wolność religijna dziecka w prawie polskim, [w:] Prawa dziecka: perspektywa Kościoła, red. ks. Piotr Kroczek, Kraków 2015, s. 199-214 (Annales Canonici Monographiae, 3).

DOI: http://dx.doi.org/10.15633/9788374384353.11 